\title{
UPAYA MENINGKATKAN KETERAMPILAN BERBICARA SISWA DENGAN MENGGUNAKAN METODE REKA CERITA GAMBAR \\ Oleh
}

Sri Hartati

SMA Negeri 1 Trimurjo

Srihartati12@gmail.com

\begin{abstract}
Learning student speaking skills is an important part of teaching Indonesian. Through learning speaking skills students are expected to be able to: Dialogue with other people, Express messages, opinions, experiences and feelings logically and systematically, discussing with regard to procedures and manners, submitting reports, speeches, remarks or lectures. and verbal feelings have been learned and possessed by students before they enter school. This ability is obtained by students in the family environment and other environments outside the school environment. But the talent that this student has is not enough to make students skilled in speaking in front of the class. The purpose of this study was to improve the speaking skills of class X.4 students of SMA Negeri 1 Trimurjo. The results of this study are the skills of the students of SMA N 1 Trimrjo in speaking with their stories when the picture can be improved. This can be proven from the results that reached an average value of 55.75 after being given action I increased to 64.88 and after being given action II to 70.38
\end{abstract}

\section{Keywords - Reka Method Picture Story, Speaking Skills, Trimurjo Senior High School 1}

\section{PENDAHULUAN}

Tujuan bahasa tidak terlepas dari penggunaan bahasa, yaitu sebagai komunikasi. Sari \& Suhono menjelaskan bahwasanya "Language is a means of communication among individuals. It is a signaling system which is operated with symbolic vocal sound and which is used by a group of people for to get the purpose of communication. It is a special characteristic of human"(Sari \& Suhono, 2017). Tentunya pembelajar bahasa harus lebih terampil dalam mempraktekan skill, baik dalam oral ataupun written.

Pembelajaran bahasa Indonesia mencakup aspek mendengar, berbicara, membaca dan menulis. Ke- empat aspek tersebut sebaiknya mendapat porsi yang seimbang. Dalam pelaksanaanya sebaiknya di laksanakan secara teerpadu 9 Depdikbud, 2004 ).

Salah satu materi pengajaran yang terpadu tersebut adalah pengajaran keterampilan berbicara. Keterampilan berbicara mencakup empat aspek pembelajaran. Keterampilan berbicara di awali dengan kegiatan membaca atau mendengarkan lalu menuliskan apa yang di baca atau di dengar setelah itu siswa lain mendengarkan.

Berdasarkan fungsi dan tujuan pendidikan nasional, jelas bahwa pendidikan di setiap jenjang, termasuk di sekolah harus diselenggarakn secara sistematis (Ahmad, Kristiawan, Tobari, \& Suhono, 2017) .Dalam kurikulum 2004, pengajaran keterampilan berbicara di ajarkan di kelas X, XI, dan XII. Keterampilan berbicara yang di miliki siswa 
membantu dan mempermudah siswa dalam berdiskusi, mengungkapkan ide tau perasaannya, sehingga mudah memahami materi pelajaran, tidak hanya untuk pelajaran bahasa Indonesia saja, tetapi juga untuk pelajaran lain.

Pada penelitian ini yang menjadi variabel bebas $(x)$ adalah metode reca cerita gambar. Sedangkan aktifitas dan hasil belajar merupakan variabel terlihat (y). Dalam rangka memberi jawaban sementara tentang masalah yang akan diteliti sehingga memperjelas penelitian yang akan dilakukan.

Hasil belajar yang di peroleh siswa berbeda-beda, hal ini disebabkan karena adanya faktor yang mempengaruhinya, faktor tersebut dapat berasal dari faktor-faktor luar siswa maupun faktor dalam diri siswa itu sendiri.

Keadaan yang ideal dalam proses pembelajaran, siswa belajar dengan sungguh-sungguh, besemangat dan penuh perhatian, bila keadaan seperti itu terwujud dapat dikatakan proses belajar mengajar belajar efektif. Keadaan demikian dapat terwujud dengan menggunakan strategi atau metode pembelajaran yang tepat yang dapat menarik siswa untuk terlibat secara penuh selama proses pembelajaran berlangsung.

Sehubungan dengan hal diatas, penggunaan metode pembelajaran yang tepat yaitu menggunakan metode reca cerita gambar sebagai salah satu alternatif dalam proses belajar mengajar karena metode reca cerita gambar dapat menumbuh kembangkan keterampilan berfikir anak, sehingga dapat membangkitkan motivasi belajar siswa.

Pembelajaran metode reca cerita gambar memiliki hubungan yang erat dengan hasil belajar, karena pembelajaran dengan menggunakan metode reca cerita gmbar dapat membantu siswa memahami suatu wacana yang sulit, siswa dilatih berbicara memngungkpkan suatu masalah yang diberikan oleh guru diharapkan menjadi alterrnatif pembelajaran berbicara Bahasa Indonesia yang Efektif.

Hasil belajar merupakan perpaduan antara proses (suatu aktivitas) dan perolehannya. Sebagaimana dinyatakan Suryabrata (2000), hasil belajar termasuk dalam kelompok atribut kognitif yang 'respons' hasil pengukurannya tergolong pendapat (judgment), yaitu respon yang dapat dinyatakan benar atau salah. Menurut Briggs (1979), hasil belajar adalah seluruh kecakapan dan segala hal yang diperoleh melalui proses belajar mengajar di sekolah yang dinyatakan dengan angka dan diukur dengan menggunakan tes hasil belajar. Sudjana (1990), mendefinisikan hasil belajar sebagai kemampuan-kemampuan yang dimiliki peserta didik setelah ia menerima pengalaman belajar. Soedijarto (1993), menyatakan bahwa hasil belajar adalah tingkat penguasaan yang dicapai oleh pelajar dalam mengikuti program belajar mengajar sesuai dengan tujuan pendidikan yang ditetapkan. 
Sesuai dengan prinsip-prinsip belajar di atas, maka untuk memperoleh hasil belajar yang optimal, dibutuhkan tiga tahap kegiatan yaitu: 1) persiapan belajar, 2) pelaksanaan belajar, dan 3) pengendalian belajar. Pada tahap persiapan yang harus dilakukan peserta didik adalah menyiapkan situasi dan kondisi belajar yang menyenangkan yaitu meliputi; menyiapkan ruang belajar yang bersih, pencahayaan dan ventilasi yang baik, memelihara kesehatan jasmani, emosional dan sosial, mengatur waktu belajar, menyiapkan bahan pelajaran dan alat tulis yang dibutuhkan.

Hasil belajar peserta didik di sekolah merupakan indikasi produk dari proses pembelajaran di sekolah. Dalam proses tersebut peserta didik telah mengalami berbagai upaya sehingga terjadi transformasi pengetahuan (kognitif), sikap (afektif), maupun keterampilannya (psikomotorik). Di dalam proses belajar, maka hasil belajar peserta didik tidak lain adalah hasil belajar.

Menurut Winkel (1983), hasil belajar merupakan hasil yang telah dicapai melalui pengalaman belajar. Oleh karena pengalaman menjadi bagian dari proses pembelajaran, maka dengan proses pembelajaran yang baik di sekolah akan menghasilkan hasilbelajar yang tinggi. Hasil belajar peserta didik dipengaruhi oleh berbagai faktor. Menurut Ahmadi (1982), salah satu faktor yang mempengaruhi hasil belajar adalah faktor indogen,yaitu faktor yang timbul dari dalam diri peserta didik.
Seperti faktor biologis (jasmaniah) dan faktor psikologis (faktor rohaniah).

Winkel (1982) menguraikan lebih jauh tentang berbagai faktor yang mempengaruhi hasil belajar peserta didik sebagai berikut: 1) Faktor Intern. Faktor intern bersumber dari dalam diri peserta didik. Faktor ini dapat dibedakan menjadi faktor intelektual dan non-intelektual. Faktor intelektual meliputi taraf intelegensi, kemampuan belajar, dan cara belajar. Sedangkan, faktor non-intelektual meliputi: motivasi, sikap, perasaan, minat, kondisi psikis, dan kondisi akibat keadaan sosiokultural. 2) Faktor Ekstern. Faktor ekstern bersumber dari luar diri peserta didik. Faktor meliputi 3 unsur, yaitu: (1) faktor pengatur proses belajar di sekolah (kurikulum pengajaran, disiplin belajar, efektivitas Pendidik, fasilitas belajar, dan pengelompokan peserta didik; (2) faktorfaktor sosial di sekolah (sistem sosial, status sosial, dan interaksi Pendidik peserta didik); dan (3) faktor-faktor situasional (keadaan politik, ekonomi, waktu dan tempat, dan keadaan iklim).

Dari tinjauan teoretis tentang hasil belajar di atas terlihat bahwa hasil belajar peserta didik terkait baik dengan aspek individual maupun lingkungan peserta didik. Terutama pada aspek individual, maka menyangkut intelektual hasil belajar tidak dapat dipisahkan dengan kemampuan belajar yaitu menyangkut konsep diri dan cara belajar, yaitu menyangkut intensitas dalam belajar maupun penggunaan waktu 
belajar. Di lain pihak pada faktor rohaniah dari individu peserta didik, seperti halnya kesalehan turut mempengaruhi hasil belajar peserta didik. Dengan demikian dapat disimpulkan bahwa hasil belajar merupakan pencapaian hasil belajar peserta didik di sekolah setelah mengikuti proses pembelajaran di kelas yang melibatkan berbagai faktor baik faktor diri peserta didik yang bersifat intelektual maupun nonintelektual.

\section{METODE PENELITIAN}

Subjek penelitian ini adalah siswa kelas $X 4$ SMAN 1 Trimurjo, berjumlah 40 siswa yang terdiri dari 14 orang purta dan 26 orang putri. Peneliti menggunakan teknik pengumpulan data, yaitu observasi dan test. Syarwani menjelaskan observasi digunakan untuk menggali data dari sumber data yang berupa peristiwa, tempat atau lokasi dan benda serta rekaman gambar (Ahmad dkk., 2017: 410)

\section{HASIL PENELITIAN DAN PEMBAHASAN}

Kemampuan berbicara siswa kelas $X$ 4 yang berjumlah 40 siswa yang tuntas baru 5 oang yaitu, Ani handayani jumlah skor 70 , Bungles Kasfer skor 70, Dian Khusnul skor 70, Tia Maretha skor 70, dan Tika Kurnia skor 70, aspek yang dinilai pada kemampuan berbicara yaitu keterrampilan isi, sistematika pembicaraan, penggunaan Bahasa dan Kelancaran berbicara.

\section{A. Siklus 1}

1. Perencanaan

Pada tahap persiapan penelitiian melakukan kebiatan sebagai beikut :

a. Menyusun skenario pembelajaran

b. Merancang model pembelajaran yang mendukung penapaian peningkata keterrampilan berbicara siswa dengan metode reca cerita gambar.

c. Menyiapkan media berupa gambar yang terdiri dari 2-4 gambar untuk penelitian siklus 1 .

d. Merancang alat evaluasi untuk melihat apakah ada peningkatan keterampilan berbicara yang dicapai siswa. Evaluasi merupakan kegiatan yang dilakukan seorang guru kepada anak didiknya untuk mendapatkan data sejauh mana keberhasilan mereka dalam belajar. Agar tujuan pendidikan lebih terarah dan tercapai dengan baik seorang pendidik harus memberikan contoh dalam bentuk prilaku (Suhono \& Utama, 2017).

e. Menyiapkan catatan lapangan untuk mendapatkan data selama kegiatan mengajar berlangsung

\section{Pelaksanaan Tindakan}

Kegiatan penelitian dalam siklus 1 ini menggunakan 3 RPP, masing-masing RPP disesuaikan dengan standar kompetensi dan kmpetensi dasar. 
Untuk kelas $X$ pada siklus 1 ini peneliti memillih standar kompetensi 2. Mengungkapkan pikiran, perasaan, dan informasi melalui kegiatan berkenalan, berdiskusi dan becerita. Dengan kompetensi dasar 2.1. memperkenalkan diri dan orang lain didalam forum resmi dengan intonasi yang tepat. 2.2. mendiskusikan masalah (yang ditemuikelkan dari berbgai berita artikel atau buku). 2.3. menceritakan berbagai pengalaman dengan pilihan kata dan ekspresi yang tepat. Secara umum model pembelajaran yang dipakai menggunakan metode diskusi kelompok, metode diskusi ini dipilih supaya siswa mendapat kesempatan untuk berlatih berbicara lebih banyak lagi. Pada setiap pembelajaran guru memberikan gambar yang menunjang RPP. Pada pertemuan 1. Kegiatan yang dilaksanakan pada tahap ini adalah melaksnakan pembelajaran sesuai dengan renana yang telah ditentukan. Langkah yang akan dilakukan pada pembelajaran model reka cerita gambar adalah :

1. Pendahuluan

Tahap ini adalah sarana pembelajaran, membuka pembelajaran, memotivasi siswa dan menyampaikan tujuan pembelajaran.

2. Kegiatan Inti

a. Guru mengrganisasikan siswa dalam kelompok yang terdiri dari 4-5 siswa secara heterogen sesuai dengan jumlah siswa. b. Setiap kelompok mendapat satu gambar yang sesuai dengan materi pelajaran yang diberikan oleh guru.

c. Siswa bekerja sama mengamati gambar dan menemukan masalah yang ada pada gambar.

d. Siswa secarra individu menyampaikan hasil pengamatannya dipandu gambar.

3. Penutup

Guru bersama siswa menyusun kesimpulan, dan guru menutup pelajaran.

Pada pertemuan 2 dengan kompetensi dasar mendiskusikan masalah (yang ditemukan dari berbagai berita, artikel atau buku).

Pada pertemuan awal guru membagi kelompok diskusi kemudian membagikan gambar dan siswa mengamati masalah yang ada pada gambar, siswa mendiskusikan masalah berita yang ada pada gambar dan memberi tanggapan, guru mengamati aktivitas siswa dalam berdiskusi. Terlihat diskusi yang dipandu gambar sangat meriah. Guru memotivasi siswa untuk mengungkapkan tanggapannya, meskipun masih ada siswa yang belum aktif berbicara, memberi kesempatan siswa untuk tampil ke depan kelas. Pada Pertemuan 3 Kompetensi dasar menceritakan berbagai pengalaman dengan pilihan kata dan ekspresi yang tepat. Dengan kegiatan awal setelah mengkondisikan kelas, guru membagikan gambar kepada kelompok belajar. Semua siswa mengamati gambar bertanya jawab 
tentang masalah yang ada pada gambar. Kemudian berlatih menceritakan berbagai pengalaman yang sesuai dengan gambar, kemudian guru memberi kesempatan kepada siswa untuk menceritakan berbagai pengalaman dengan pilihan kata dan ekspresi yang tepat dengan panduan gambar yang diberikan. Terlihat kegiatan yang di pandu gambarr sangat menarik dan siswa termotovasi untuk berbicara meskipun masih ada siawa yang belum aktif berbicara oleh karena itu kegiatan penelitian ini akan dilanjutkan pada siklus 2

3. Hasil Pengamatan

Pengamatan dilakukan dengan menggunakan lemba bervariasi yang telah disediakan dan dilaksanakan selama kegiatan pembelajaran.

Pengamatan yang dilakukan berupa pengamatan terhadap aktivitas belajar siswa selama proses pembelajaran baerlangsung aktivitas tersebut adalah memperhatikan gambar, melaksanakan diskusi kelompk, memberikan tanggapan terhadap gambar, menggunakan bahasa indonesia yang baik dan benar, melafalkan kata dengan tepat, mampu bercerita secara lancar.

4. Refleksi

Refleksi adalah kegiatan menganalisis, memahami dan membuat perbaikan berdasarkan pengamatan dan catatan lapangan. Perbaikan dilakukan dengan meliihat hasil evaluasi terhadap desain pembelajaran yang dilakukan oleh guru. Aktifitas dan hasil belajar siswa dengan menggunakan metode reka cerita gambar. Apabila hasil evaluasi telah mencapai target yang diinginkan maka peneliitii akan meneruskan proses pembelajaran. Tetapi hasil evaluasi yang dilakukan pada tindakan siklus 1 belum mencapai terget yang diinginkan penelitin akan melakkuka pembagian pada siklus 2 .

\section{B. Siklus 2}

1. Perencanaan

Pada tahap persiapan peneliti melakukan kegiatan

a. Menyusun skrnario pembelajaran

b. Merancang model pembelajaran yang mendukung pencapaian peningkatan keterampilan berbicara siswa dengan metode reka cerita gambar.

c. Menyiapkan media berupa gambar yang terdiri dari 1-2 gambar untuk penelitian siklus 2 .

d. Merancang alat evaluasi untuk melihat apakah ada peningkatan keterampilan berbicara yang dicapai siswa.

e. Menyiapkan catatan observasi dan catatan lapangan untuk mendapatkan data selaha kegiatan belajar mengajar berlangsung.

\section{Pelaksanaan Tindakan}

Kegiatan penelitian dalam siklus 2 ini menggunakan 2 RPP. Masing-masing RPP disesuaikan dengan standar kompetensi dan kompetensi dasar. 
Pada siklus 2 ini peneliti memilih standar kompetensi 6.1. Mengemukakan hal-hal yang menarik atau mengesankan dari cerita pendek melalui kegiatan diskusi dan kompetensi dasar 6.2. Menemukan nilainilai cerita pendek melalui kegiatan diskusi. Model pembelajaran yang dipakai menggunakan model diskusi kelompok. Pada setiap pembelajaran guru memberikan gambar yang menunjang RPP. Pada pertemuan 1 kegiatan yang dilaksanakan pada siklus 2 ini adalah melaksanakan pembelajaran sesuai dengan rencana yang telah ditentukan. Langkah yang akan dilakukan pada pembelajaran model reka cerita gambar adalah :

1. Pendahuluan

Guru mempersiapkan sarana pembelajaran, membuka pembelajaran, memotivasi siswa dan menyampaikan tujuan pembelajaran.

2. Kegiatan Inti

a. Guru membentuk kelompk diskusi yang terdiri dari 4-5 siswa.

b. Guru membagikan gambar yang sesuai dengan materi pelajaran.

c. Siswa mengamati gambar dan menemukan masalah yang ada pada gambar.

d. Siswa secara individu menyampaikan hasil pengamatannya dipandu gambar.

3. Penutup

Guru bersama siswa menyusun kesimpulan dan guru menutup pelajaran. Pada pertemuan 2 dengan kompetensi dasar 6.2. Menemukan nilai-nilai cerita pendek melalui kegiatan diskusi. Langkah yang dilakukan pada pembelajaran model reka cerita gambar adalah :

1. Pendahuluan

Guru mengkondisikan kelas, guru mempersiapkan sarana pembelajaran, membuka pembelajaran, memotivasi siswa dan menyampaikan tujuan pembelajaran.

2. Kegiatan Inti

a. Guru membentuk kelompok diskusi yang terdiri dari 4-5 siswa.

b. Guru membagikan gambar.

c. Siswa mengamati gambar dan bersama-sama membahas masalah yang ada pada gambar.

d. Secara individu siswa menyampaikan hasil pengamatannya dipandu gambar.

3. Penutup

Guru bersama siswa menyimpulkan pembelajaran, guru menutup pembelajaran.

3. Hasil Pengamatan Siklus 2

Pengamatan dilakukan dengan menggunakan lembar observasi yang telah disediakan dan dilaksanakan selama kegiatan pembelajaran. Pengamatan yang dilakukan pada siklus 2 berupa pengamatan terhadap aktivitas belajar siswa selama proses pembelajaran berlangsung. Aktivitas yang diamati adalah memperhatikan gambar, melaksanakan diskusi kelompk, memberikan tanggapan terhadap gambar, 
menggunakan bahasa Indonesia yang baik dan benar, melafalkan kata dengan tepat, dan mampu bererita secara benar. Berdasarkan hasil pengamatan pada siklus 2, semua siswa sudah melakukan dengan baik dan benar.

4. Refleksi Siklus 2

Berdasarkan pengamatan dan catatan lapangan pada siklus 2 perbaikan sudah dilakukan dengan melihat hasil evaluasi terhadap pembelajaran yang dilakukan oleh guru. Aktivitas dan hasil belajar siswa dengan menggunakan metode reka cerita gambar, sudah mencapai perbaikan hasil yang meningkat dan tuntas individu dan tuntas klasikal.

\section{Pembahasan Tiap Siklus dan Antar Siklus}

Sebelum penelitian dimulai peneliti mengadakan tes awal. Siswa disuruh bercerita tentang pengalamannya tanpa menggunakan gambar, hasil yang diperoleh dari 40 siswa, ternyata hanya 5 orang yang tuntas dengan daya serap 70 yaitu Ani Handayani, Bungles Kefer, Dian Khusnul, Tia Maretha, Tika Kurnia. Pada siklus 1 diadakan tindakan degan menggunakan gambar. Gambar yang diberikan berjumlah 3-4. Setelah siswa mengamati gambar guru memotivasi dan memberi arahan dan menyuruh siswa tampil. Pertemuan pertama mulai kelihatan meningkat jumlah siswa yang sudah tuntas meningkat menjadi 7 siswa, yaitu Ajeng Pratiwi, Ani Handayani, Bungles Kefer, Dian Khusnul, Endra
Permana, Tia Maretha dan Tika Kurnia yang lain juga sudah meningkat meskipun belum tuntas. Pada pertemuan ke-2 siswa diberi gambar yang swsuai dengan materi mendiskusikan masalah yang ada dari berbagai berita atau artikel) setelah dilakukan kegiatan ternyata hasil yang diperoleh juga meningkatkat yang sudah tuntas menjadi 9 sisw yaitu Ajeng Fitriani, Angga Prasetya, Ani Handayani, Bungles Kefer, Dian Khusnul, Endra Permana, Muh. Kristian, Tia Mareta dan Tika Kurnia yang belum tuntas juga sudah meningkatkan hasilnya. Pada prtemuan ketiga siswa diberi gambar uang sessuai dengan materi menceritakan berbagai pengalaman dengan pilihan kata dan ekspresi yang tepat. Setelah guru membagikan gambar siswa mengamati, berdiskusi dan maju menceritakan pengalamannya dipandu gambar. Ternyata hasilnya meningkat menjadi 24 siswa yang tuntas yaitu, Ahmad Irawan, Ajeng Fitriani, Ani Handayani, Bungles Kefer, Diankhusnul, Endra Permana, Erma Fitriani, Hermando, Indria Eka Santi, Ivo Soleha Tia Agustina, Liza Erena, Juzi Seprida, Muh. Kristian, Nandang, Rini Lestari, Sutri Mariah, Tia Mareta, Tika Kurnia Tri Arisma, Tuana Hermayadi, meskipun yang tuntas klasihal oleh sebab itu dilanjutkan dengan tinddakan siklus 2.

Pada siklus 2 ini peneliti mengurangi jumlah gambar, pada siklus 1 jumlah gambar yang di berikan 3-4 gambar namun pada siklus 2 peneliti mengurangi gambar menjadi 
1-2, pengurangan gambar dimaksud kan agar siswa tidak ketergantungan dengan gambar yang diberikan. Pada pertemuan 1 siklus 2 guru membagikan gambar yang sesuai dengan kompetensi dasar 6.1. mengmukakan hal-hal yang menarik atau mengesankan dari cerita pendek melalui kegiatan diskusi.siswa mengamati gambar yang di berikan kemudian siswa mendiskusikan cerita yang ada pada gambar dan siswa diberikan kesempatan utnuk menceritakan cerpen dengan dipandu gambar hasilnya semakin menignkat, sisw begitu bersemangat dan mulaii lancar berceritanya. Jumlah yang tuntas sudah mencapati 30 siswa. Pada pertemuan 2 siklus 2. Peneliti mengambil kompetensi dasar 6.2. menemukan nilai-nilai cerita pendek melalui kegiatan diskusi, guru membagikan gambar berjumlah 1, siswa mengamati gambar bersama teman kelompok diskusinya lalu guru di beri kesempatan unruk mengemukakan nilai-nilai cerita pendek, dan hasilnya sangat fantastik semua siswa antusiasi ingin maju duluan. Hingga 40 siswa semuanya tuntas meskipun gambar dikurangi dan pada tes akhir siswa bercerita tanpa menggunakan gambar.

\section{Hasil Penelitian}

Penelitian yang peneliiti lakukan adalah penelitian tindakan kelas dengan metode reka cerita gambar. Sebelum dilakukan tindakan peneliti melakukan tes awal untuk mengetahui kemampuan berbicara siswa kelas X 4 SMA N ! Trimurjo. Hasil yang peneliti dapatkan dari tes awal
(TO) kemampuan berbicara. Dari 40 siswa baru 5 siswa yang tuntas secara individu dengan nilai rata-rata 55,75 (lima puluh lima koma tujuh lima) setelah dilakukan tindakan 1 nilai rata-rata yang diperoleh siswa menjadi 64,88 (enam puluh empat koma delapan delapan) dan setelah diberikan tindakan 2 meningaktkan menjadi 70,38 (tujuh puluh koma tiga delapan). Persentasi ketuntasan belajar siswa secara klasikal pun meningakat. Pada tes awal ketuntasan belajar siswa $12,5 \%$ sudah diberi tindakan 2 meningkat menjadi $100 \%$ Untuk mengetahui peningkatan hasil belajar siswa sebelum tindakan (TO) setelah tindakan ( $\mathrm{TI}$ ) dan tindakan 2 (T2) dapat dilihat pada tebel 1 berikut.

Tabel 1

Hasil Peneliitinan Tindakan Kelas

Sebelum Tindakan ( $\mathrm{T}$ ) Tes Setelah Tindakan (T1) Dan Nilai Tes Tindakan (T2)

\begin{tabular}{|l|c|c|c|c|c|}
\hline \multicolumn{1}{|c|}{$\begin{array}{l}\text { Nama } \\
\text { Siswa }\end{array}$} & T0 & T1 & T2 & \multicolumn{2}{|c|}{ Tuntas } \\
\cline { 4 - 6 } & & & Ya & Tidak \\
\hline $\begin{array}{l}\text { Ahmad } \\
\text { Irawan }\end{array}$ & 55 & 65 & 70 & $\sqrt{ }$ & \\
\hline $\begin{array}{l}\text { Ajeng } \\
\text { Fitriani }\end{array}$ & 60 & 70 & 75 & $\sqrt{ }$ & \\
\hline $\begin{array}{l}\text { Angga } \\
\text { Prasetya }\end{array}$ & 50 & 60 & 65 & $\sqrt{ }$ & \\
\hline $\begin{array}{l}\text { Ani } \\
\text { Handayani }\end{array}$ & 70 & 80 & 85 & $\sqrt{ }$ & \\
\hline Arik Budi & 60 & 65 & 70 & $\sqrt{ }$ & \\
\hline $\begin{array}{l}\text { Berta } \\
\text { Pratiwi }\end{array}$ & 50 & 60 & 65 & $\sqrt{ }$ & \\
\hline $\begin{array}{l}\text { Bungles } \\
\text { Kasfer }\end{array}$ & 70 & 80 & 85 & $\sqrt{ }$ & \\
\hline $\begin{array}{l}\text { Dani } \\
\text { Susiwi }\end{array}$ & 55 & 65 & 70 & $\sqrt{ }$ & \\
\hline Dhomiko & 60 & 65 & 70 & $\sqrt{ }$ & \\
\hline Dian & 70 & 75 & 80 & $\sqrt{ }$ & \\
\hline
\end{tabular}




\begin{tabular}{|c|c|c|c|c|c|}
\hline Khusnul & & & & & \\
\hline $\begin{array}{l}\text { Dian } \\
\text { Yunita }\end{array}$ & 50 & 60 & 70 & $\sqrt{ }$ & \\
\hline Eri Eryana & 50 & 60 & 65 & $\sqrt{ }$ & \\
\hline $\begin{array}{l}\text { Endra } \\
\text { Permana }\end{array}$ & 60 & 70 & 75 & $\sqrt{ }$ & \\
\hline $\begin{array}{l}\text { Erma } \\
\text { Fitriyani }\end{array}$ & 50 & 60 & 65 & $\sqrt{ }$ & \\
\hline $\begin{array}{l}\text { Erma } \\
\text { Yuswanti }\end{array}$ & 50 & 60 & 65 & $\sqrt{ }$ & \\
\hline $\begin{array}{l}\text { Fitri } \\
\text { Lestari }\end{array}$ & 50 & 60 & 65 & $\sqrt{ }$ & \\
\hline Hernando & 55 & 65 & 70 & $\sqrt{ }$ & \\
\hline $\begin{array}{l}\text { Indri Eka } \\
\text { Santi }\end{array}$ & 60 & 65 & 70 & $\sqrt{ }$ & \\
\hline $\begin{array}{l}\text { Indri } \\
\text { Yanto }\end{array}$ & 60 & 65 & 70 & $\sqrt{ }$ & \\
\hline $\begin{array}{l}\text { Ivan } \\
\text { Kurniawan }\end{array}$ & 50 & 60 & 70 & $\sqrt{ }$ & \\
\hline Ivo Soleha & 50 & 60 & 70 & $\sqrt{ }$ & \\
\hline $\begin{array}{l}\text { Lia } \\
\text { Agustina }\end{array}$ & 50 & 65 & 70 & $\sqrt{ }$ & \\
\hline $\begin{array}{l}\text { Liza } \\
\text { Enena }\end{array}$ & 50 & 60 & 65 & $\sqrt{ }$ & \\
\hline $\begin{array}{l}\text { Luzi } \\
\text { Seprida }\end{array}$ & 50 & 60 & 65 & $\sqrt{ }$ & \\
\hline Maisaroh & 50 & 60 & 75 & $\sqrt{ }$ & \\
\hline $\begin{array}{l}\text { Muh. } \\
\text { Kristian }\end{array}$ & 60 & 70 & 70 & $\sqrt{ }$ & \\
\hline Nandang & 60 & 65 & 70 & $\sqrt{ }$ & \\
\hline $\begin{array}{l}\text { Rini } \\
\text { Lestari }\end{array}$ & 55 & 65 & 70 & $\sqrt{ }$ & \\
\hline Siti Amiati & 50 & 65 & 65 & $\sqrt{ }$ & \\
\hline Sukirno & 50 & 60 & 70 & $\sqrt{ }$ & \\
\hline $\begin{array}{l}\text { Susiana } \\
\text { Wati }\end{array}$ & 50 & 65 & 70 & $\sqrt{ }$ & \\
\hline $\begin{array}{l}\text { Sutri } \\
\text { Mariah }\end{array}$ & 60 & 65 & 85 & $\sqrt{ }$ & \\
\hline $\begin{array}{l}\text { Tia } \\
\text { Maretha }\end{array}$ & 70 & 80 & 80 & $\sqrt{ }$ & \\
\hline $\begin{array}{l}\text { Tika } \\
\text { Kurnia }\end{array}$ & 70 & 75 & 65 & $\sqrt{ }$ & \\
\hline Tri Arisma & 50 & 60 & 65 & $\sqrt{ }$ & \\
\hline $\begin{array}{l}\text { Triana } \\
\text { Hermayadi }\end{array}$ & 50 & 60 & 70 & $\sqrt{ }$ & \\
\hline Umi & 50 & 60 & 70 & $\sqrt{ }$ & \\
\hline
\end{tabular}

\begin{tabular}{|l|c|c|c|c|c|}
\hline Kalsum & & & & & \\
\hline $\begin{array}{l}\text { Weni } \\
\text { Wijaya }\end{array}$ & 60 & 65 & 70 & $\sqrt{ }$ & \\
\hline Wiyani & 60 & 65 & 70 & $\sqrt{ }$ & \\
\hline $\begin{array}{l}\text { Yuli } \\
\text { Apriyani }\end{array}$ & 50 & 60 & 65 & $\sqrt{ }$ & \\
\hline $\begin{array}{c}\text { RATA- } \\
\text { RATA }\end{array}$ & 55.75 & 64.88 & 70.38 & & \\
\hline
\end{tabular}

\section{KESIMPULAN}

Berdasarkan penelitian dan pembahasan dapat disimpulkan, keterampilan siswa SMA N 1 Trimrjo dalam berbicara dengan pila reka cerita gambar dapat ditingkatkan. Hal ini dapart dibuktikan dari hasil yang mencapai nilai rata-rata 55,75 setelah diberi tindakan I meningkat menjadi 64,88 dan setelah diberi tindakan II menjadi 70,38. Dengan demikian hipotesis yang di ajukan pada penelitian yaitu dengan pola reka cerita gambar keterampilan berbicara siswa kelas X 4 SMA N 1 Trimurjo dapat ditingkatkan terrbukti kebenarannya. Sebagai implikasi jika siswa telah terampil berbicara dengan baik diharapkan siswa akan mampu mengungkapkan ide, perasaannya dan pendapatnya dalam kehidupannya di masyarakat.

\section{DAFTAR PUSTAKA}

Ahmad, S., Kristiawan, M., Tobari, T., \& Suhono, S. (2017). Desain Pembelajaran SMA Plus Negeri 2 Banyuasin III Berbasis Karakter Di Era Masyarakat Ekonomi ASEAN. lqra': Jurnal Kajian IImu Pendidikan, 2(2), 403-432.

Ari Kunto, Suharsimi. 2006. Prosedur Peelitian Suatu Pendekatan Praktik. Jakarta : PT. Rineka Cipta.

Ahmad, S., Kristiawan, M., Tobari, T., \& Suhono, S. (2017). Desain 
Pembelajaran SMA Plus Negeri 2 Banyuasin III Berbasis Karakter Di Era Masyarakat Ekonomi ASEAN. Iqra': Jurnal Kajian IImu Pendidikan, 2(2), 401

Dedikbud, 1995. Kamus Besar Bahasa Indonesia. Jakarta : Balai Pustaka.

Depdiknas, 2003. Kurikulum 2004 SMA. Jakarta : Depdiknas

Hamalik, Oemar. 2001. Proses Belajar Mengajar, Jakarta : Bumi Aksara

Kosasi, Englos. 2008. Cerdas Berbahasa Indonesia $X$. Jakarta : Erlangga

Mudjiono dan Dimiyati : 2002. Belajar dan Pembelajaran. Jakarta: Direktorat Jendral Pendidikan Tinggi

Sari, Y. A., \& Suhono, S. (2017). Applaying Transition Action Detail Strategy on Written Text of EFL Young Learners. Iqra': Jurnal Kajian IImu Pendidikan, 2(1), 1-24

Sagala, Syaiful, 2007. Konsep dan Makna Pembelajaan, Bandung : Alfabeta.

Sardiman, AM. 2001. Interaksi Motivasi Belajar Mengajar. Jakarta : Raja Gratindo Persada

Suryanto, Alex dan Agus Haryanta, 2007. Panduan Belajar Bahasa dan Sastra Indonesia $X$. Tanggerang : Esi

Sidharta, A. 2004. Pembelajaran Kooperatif. Modul Diklat Berjenjang. Bandung: Depdiknas, Ditjen Dikdasmen, Pusat Pengembangan Penataran Pendidik IPA

Suhono, S., \& Utama, F. (2017). Keteladanan Orang Tua Dan Guru Dalam Pertumbuhan Dan Perkembangan Anak Usia Dini. Elementary: Jurnal Ilmiah Pendidikan Dasar, 3(2), 107-119.

Sudjana, Nana. (1990). Teori-teori Belajar untuk Pengajaran. Jakarta: FE UI

Selameto, 2003. Belajar dan Faktor-faktor yang Mempengaruhinya. Jakarta : Rineka Cipta.

Tarigan, 1997. Keterampilan Berbicara. Jakarta : Balai Pustaka.

Triatno, 2007. Model-model Pembelajaran Inovatif Berorientasikan Kontruktivistik. Surabaya : Prestasi Surabaya.

Winkel, W.S. 1983. Psikologi Pendidikan dan Evaluasi Belajar. Jakarta: Gramedia 